\title{
ISLAM, ISLAMISM, THE NATION, AND THE EARLY INDONESIAN NATIONALIST MOVEMENT'
}

\author{
RE Elson \\ The University of Queensland, Australia
}

\begin{abstract}
In an attempt to understand better the failure of Islamism to exercise any significant impact on the trajectory of Indonesian politics through the twentieth century, this article examines the development of Indonesian Islamist thought in the early twentieth century and compares it to the growth of secularist nationalist thinking. Islamist thinking was slow to arrive at a consciousness of Indonesia as specific national place and homeland. By the time Islamist thinkers had begun to develop a clearer sense of their own political project, secular nationalist thinkers (often indifferent to and sometimes fiercely opposed to Islamic and Islamist ideas about the relationship of state to religion) had already established the unassailable primacy of the idea of Indonesia as an independent sovereign state-inthe-making and as the vehicle for Indonesians to become both modern and prosperous. Islamists thereafter had no option but to seek to accommodate their thinking to the dominant paradigm of the idea of Indonesia.
\end{abstract}

Keyword: Islamism, nationalist movement, modernist Islam, reformist Islam, secularism.

\section{Introduction}

Why has Indonesian Islamism (by which I mean that understandding which demands that the exercise of politics be grounded upon Islam above all else) failed for so long to have a significant, consequential impact on the course of Indonesia's twentieth century history and politics? As Bahtiar Effendy notes, "In Indonesia Islam has long been at an impasse in terms of its political relationship with the state." 2

\footnotetext{
${ }^{1}$ I am grateful for the comments of John Butcher, Akh Muzakki, Kees van Dijk and Michael Laffan on an earlier version of this paper.

2 Bahtiar Effendy, Islam and the State in Indonesia (Singapore: ISEAS, 2003), p. 2.
} 
In beginning to address this problem, I have found it useful to focus on an analysis of Islamism's engagement with the discourses and directions of early Indonesian nationalism. It was there, I shall argue, that the seeds of Islamism's later failures were sown.

\section{Islam and the Nationalist Narrative}

The received orthodoxy of Indonesia's coming to be as a modern nation-state is, we all know, a determinedly secular one; the narrative traces the emergence and struggles of a modernising young elite endowed with Westernised visions of nation, progress, prosperity, and tolerance. After some encouraging but ultimately false starts grounded in ethnicity, religion and international communism, the nationalist narrative takes flight with the inclusivist affirmation of the nation-ness of the whole archipelago which, the narrative goes, reaches its natural and necessary goal in Sukarno's proclamation of the independence of the Republic of Indonesia in August 1945.

Scholars and commentators have questioned whether the political shape Indonesia eventually took might have taken other forms - perhaps a federal state, perhaps a multiplicity of states, perhaps different constitutional architecture- but there has been surprisingly sparse analysis of the possibilities of an outcome in which Indonesia shaped its sense of self by virtue of the dominance, or even the significant input of, the Islamic impulse. The question may be put in variously graded ways, ranging from asking why Indonesia did not assume the form of an Islamic state to inquiring into why specifically Islamic thinking of any kind had such marginal input and importance in the final outcome. Laffan has spoken of Anderson's "heroic invocation" of the secular nationalist endeavour in Indonesia, remarking that "Anderson was not speaking of a project that identified in any substantial way with the faith of the majority of the inhabitants of the archipelago," and asserting the "real need for a re-examination of the place of religion in guiding the footsteps of some of Anderson's heroes." 3 For Laffan, "the vision of a linear development of an Indonesian nationalism evolving from diverse regional nationalism all tied to the Western metropole and class struggle is neither simple nor completely satisfying." 4 This article takes up Laffan's challenge, and in

\footnotetext{
${ }^{3}$ Michael Francis Laffan, Islamic Nationbood and Colonial Indonesia: The Umma below the Winds (London: RoutledgeCurzon, 2003), p. 2.

${ }^{4}$ Ibid., p. 166.
} 
so doing attempts to explain the failure of Islam's champions to inject any wavering into the trajectory of secularised thinking about the emerging Indonesian state.

\section{Indonesian Muslims}

Scholars generally agree that the rise of modern varieties of thinking about indigenous identity was occasioned by the Netherlands' final success in melding a new, archipelago-wide political entity which it called the Netherlands Indies and, more important, imbuing that entity with the essential characteristics of a modern state, a centralised form of governance, an efficient bureaucracy staffed by the products of modern Western education, and integrating physical and communications infrastructures -roads, railways, shipping lines, banks, newspapers.

By far the greater part of the population of this newly fabricated Netherlands Indies state of the early twentieth century was Muslim, and had long been so. Ricklefs observes of Java in the later eighteenth and earlier nineteenth centuries that "nothing in the records of this period ... implies that it was possible to be Javanese without being Muslim." 5 But Islam, like the country itself, was changing. Ricklefs has argued vigorously and industriously, if not altogether compellingly, that in Java from about the mid-nineteenth there had begun a process of polarisation within Islam, resulting in the emergence of "two groups defined by their Islamic commitment," 6 devout and pious Muslims (putihan or santri) and, in the great majority, abangan, those much less strongly attached to orthodox belief and practice, and even of the development of a striking if limited sense of outright opposition to Islam's ascendancy. ${ }^{\text {? }}$

The motor of this change in Java, he argues, was the increasing prosperity brought into domestic commercial circles — "a native bourgeoisie of Islamic bent" - by the transformative operation of the Dutch system of forced cultivations, allowing them enhanced status ${ }^{9}$

${ }^{5}$ M.C. Ricklefs, Mystic Synthesis in Java: A History of Islamization from the Fourteenth to the Early Nineteenth Centuries (Norwalk CT: EastBridge, 2006), p. 225.

6 Ibid., p. 6.

7 M.C. Ricklefs, Polarising Javanese Society: Islamic and Other Visions (c. 1830-1930) (Singapore: NUS Press, 2007), p. 86.

8 Ibid., p. 28.

${ }^{9}$ Ibid., p. 28. 
and even the chance to avail themselves of the ever-opening opportunities to travel to Mecca. There they encountered the reforming winds gusting through Middle Eastern Islam, and brought that reform-minded thinking home with revivalist enthusiasm. Its vigorous introduction may well have excited a deep adverse reaction which took gradual shape in the emergence of the abangan, with all the potential for conflict and misunderstanding that entailed. ${ }^{10}$

Whatever the case, like the emerging country itself, the Islam lived by Indonesians expressed itself in multiple manifestations, influenced by both imported and locally-forged experience, including varieties of Middle Eastern reformism (notably turn-of-the-century modernist Islam), and indigenised mystical varieties soaked with Sufistic accommodations and selective borrowings. There were, as well, Javanese Christians - a new phenomenon- and even "Javanese intellectuals who wrote works of literature saying that the Islamization of Java was a great mistake". ${ }^{11}$ Many late nineteenth century observers, indeed, cast doubts on the reality of Islamic orthodoxy, especially in Java. The Dutch missionary Poensen, while admitting that "the people on the outside are very certainly Mohammedan," thought that "in the depths of the soul there still works a religious life that expresses itself in all kinds of non-Mohammedan ideas and forms."12 Another observer noted that though "the native people profess Islam ... most of them are not Mohammedans in the real sense, far from that. The Javan, the ordinary villager, is much more attached to making offerings for various spirits than to the prescriptions of the Koran, which he very seldom observes, indeed he often pokes fun at the santri who does this." 13

That "thin and flaking glaze" conception of Indonesian Islam, sometimes put to encourage the prospects for Christian missionising, was staunchly rejected by others. Cipto Mangunkusumo, Dutcheducated medico, intellectual, and free spirit, remarked that "our

\footnotetext{
${ }^{10}$ Ricklefs, Polarising Javanese Society, pp. 95, 103-04.

11 Ricklefs, Mystic Synthesis, p. 231. For more detailed discussions, see also Ricklefs, Polarising Javanese Society, pp. 46, 175, 177, 181-82, 212.

12 C. Poensen, Brieven over den Islam uit de Binnenlanden van Java (Leiden: E.J. Brill, 1886), p. 6 [1883].

13 Boeka [P.C.C. Hansen Jr], "De Inlander, Een Studie," De Indische Gids 25 (1903), p. 1137.
} 
fathers and forefather have believed in that religion for centuries, whether they understood it or not, with their lips and with their hearts -that says it all .... The fact that we are 'syncretists' ... changes nothing: we go about our business in the holy understanding that we are Muslims!"14 Famed Dutch Islamologist Christiaan Snouck Hurgronje, in speaking of Java's Princely Territories, acknowledged that "what [the mass of the population] possess in religious and other beliefs indeed goes by the name 'Islam', but actually consists in a mixture of Indonesian, Hindi and Chinese elements." 15 Nonetheless, thought Snouck, "this does not take away the fact that chiefs and people there are mostly very attached to Islam, that they see in it a palladium of their nationality, which becomes all the more dear to them according to the measure that it is exposed to attacks from outside." 16 Nor, Snouck noted elsewhere, was that behaviour exceptional; "one comes across such a compromise between the earlier and the later civilisational situation in all Mohammedan lands, including in the stem land of Arabia." 17 Only "superficial observers", he asserted, might be moved to wonder how truly Muslim the Javanese were. ${ }^{18}$ In his analysis of West Sumatra, Van Ronkel opposed the notion of the "half-heather, half-Muslim Malay"; "all without exception want to be nothing other than Muslims."19

\section{Reformist, then Modernist Islam}

The most significant new force in the Islamic variety displayed in Indonesia was sourced half a world away in the Middle East, where Islam had been gripped by renewal. Those reformist waves sought more authentic expressions of Islam - involving "sharply articulated

\footnotetext{
14 Tjipto Mangoenkoesomo, “Dr. Kuyper te laat," Het Tijdscbrift 2 (1912), p. 574.

15 "Snouck to Directeur of Education, Worship and Industry, 21 March 1892," in Gobée and Adriaanse (eds), Ambtelijke Adviezen van C. Snouck Hurgronje 1889-1936 (The Hague: Martinus Nijhoff, 1957-65), vol. 2, p. 1077.

16 "Snouck to Director van of Education, Worship and Industry, 16 October 1894," in Gobée and Adriaanse (eds), Ambtelijke Adviezen, vol. 2, p. 1080.

17 “Snouck to Minister of Colonies, 28 October 1910," in Gobée and Adriaanse (eds), Ambtelijke Adviezen, vol. 2, p. 1099.

${ }^{18}$ C. Snouck Hurgronje, "Over Panislamisme” [1912], in A.J. Wensinck (ed.), Verspreide Geschriften van C. Snouck. Hurgronje, vol. 1 (Bonn: Kurt Schoeder, 1923), p. 375.

${ }_{19}$ Ph.S. van Ronkel, Rapport Betreffende de Godsdienstige Verschijnselen ter Sumatra's Westkust (Batavia: Landsdrukkerij, 1916), p. 14.
} 
visions of the self-sufficiency of scripture and the moral responsibility of the individual"20 - which might dispense with the thick crust of human accretions on religious belief and practice and return a more firmly grounded, intellectualised reliance on the original sources of Muslim tradition. Reformist, though not modernist, tendencies were typified in people like Ahmad Khatib, the Minangkabau madhhab scholar who left for Mecca in 1876 never to return. His thinking, best known through his fundamental criticism of the Minangkabau custom of matrilineal inheritance as contradicting the law of God and his opposition to Minangkabau mystical toriqah orders, ${ }^{21}$ was propagated through his pupils returning home and the strong links he maintained with them. ${ }^{22}$

Reformism's modernist turn involved a deep aversion to misguided human innovation (bid ab), but its privileging of the exercise of human rationality exhibited a new confidence in human capacity to interpret old traditions in ways that took better account of and sought to benefit from the reality of modernity. Such sentiments, propagated by such major figures as Jama $\gg$ al-Di al-Afgha $\gg$ and Muhłmmad Abduh, began to lap upon the island shores of the Indies at the very end of the nineteenth century, partly in consequence of technological advances such as cheap printing and steamships. ${ }^{23}$ They expressed themselves institutionally in the early years of the twentieth century in efforts at religious regeneration and the introduction of modern ways of knowing and learning. The champions of these tendencies saw themselves as a kaum muda (young group) of Muslim devotees, to be

${ }^{20}$ John R. Bowen, Muslims through Discourse: Religion and Ritual in Gayo Society (New Jersey: Princeton University Press, 1993), p. 22.

${ }^{21}$ See "Snouck to Director of Education, Worship and Industry, 29 September 1894," in Gobée and Adriaanse (eds), Ambtelijke Adviezen, vol. 3, pp. 1846-48; Murni Djamal, "The Origin of the Islamic Reform Movement in Minangkabau: Life and Thought of Abdul Karim Amrullah," Studia Islamika 5, 3 (1998), p. 6.

22 Deliar Noer, The Modernist Muslim Movement in Indonesia 1900-1942 (Kuala Lumpur: Oxford University Press, 1973), pp. 31-32; Djamal, "The origin", p. 6; Taufik Abdullah, Schools and Politics: The Kaum Muda Movement in West Sumatra (1927-1933) (Ithaca: Cornell Modern Indonesia Project, Cornell University, 1971), pp. 7-8.

23 Ahmed Ibrahim Abushouk, "A Sudanese Scholar in the Diaspora: Life and Career of Ahmad Muhamad al-Surkitti in Indonesia (1911-1943)," Studia Islamika 8, 1 (2001), p. 59 
contrasted with the old group (kaum tua), still tied to traditional Islamic practices and techniques. ${ }^{24}$

Just after the turn of the century, Indonesian Arabs formed a modern organisation, the Jamiat Khair (The Benevolent Society), which aimed at keeping pace with the rate of modern change especially through modern, Westernised education, which included religious education. ${ }^{25}$ A reformist segment of that society created the al-Irsyad education movement in 1913.26 The Muslim scholar Ahmad Dahlan, himself a former student of Khatib in Mecca, ${ }^{27}$ and profoundly influenced by the thinking of 'Abduh and his disciple Rashid Rida, formed the Yogyakarta-based modernist Muhammadiyah movement in 1912; it focussed on meeting deeply-felt indigenous educational and social needs and on selfless, rational piety as the means for Muslim salvation. ${ }^{28}$ Muhammadiyah, on a sound footing in Java by the early 1920s, was imported to Minangkabau in 1925 by the uncompromisingly aggressive Haji Abdul Karim Amrullah (Haji Rasul). That Minang connection was to prove central to Muhammadiyah's larger elaboration, and the organisation spread quickly into other regions outside Java thereafter. ${ }^{29}$

Notwithstanding its internal divisions and the varieties of its manifestation, then, Islam dominated the terrain of Indonesian ideology and thinking about identity at the turn of the twentieth century. But it remained remote from the levers that guided the flow of political events, a result of the confluence of three factors: a

\footnotetext{
${ }^{24}$ Noer, The Modernist Muslim Movement, p. 6.

25 Ibid., pp. 58, 92; Natalie Mobini-Kesheh, The Hadrami Awakening: Community and Identity in the Netherlands East Indies, 1900-1942 (Ithaca: Cornell Southeast Asia Program, 1999), p. 36-37; "Adjunct Advisor for Native affairs [Rinkes] to Governor-General, 13 May 1913," in S.L. van der Wal (ed.), De Opkomst van de Nationalistische Beweging in Nederlandsche-Indie (Groningen: J.B. Wolters, 1967), p. 202. See also Mobini-Kesheh, The Hadrami Awakening, p. 37

${ }^{26}$ Noer, The Modernist Muslim Movement, pp. 62-63.

${ }^{27}$ A. Jainuri, Mubammadiyah: Gerakan Reformasi Islam di Jawa pada Awal abad Kedua Puluh (Surabaya: PT Bina Ilmu, 1981), p. 25.

${ }^{28}$ Fauzan Saleh, Modern Trends in Islamic Theological Discourse in 20th Century Indonesia: A Critical Study (Leiden: Brill, 2001), pp. 120-21; Takashi Shiraishi, An Age in Motion: Popular Radicalism in Java, 1912-1926 (Ithaca: Cornell University Press, 1990), p. 137.

${ }^{29}$ Jainuri, Mubammadiyah, p. 42; Bowen, Muslims through Discourse, p. 56.
} 
reticence about nation, new, vital and competing cultural imaginings, and its own belated politicking.

\section{Muslim Diffidence about Nation}

Indigenous identity sometimes expressed itself in local terms, sometimes more broadly in ethnic terms (Javanese, Balinese, Acehnese, for example), and most of all in terms of religion, that is, in a shared sense of Muslim-ness that transcended any privileged attachment to a specific place. ${ }^{30}$ Islamic thinking, however, remained essentially a function of self-regarding pious thought, directed more towards individual and social behaviour and ritual than to political architecture. Within the realm of specifically Muslim thinking —of whatever stripenotions of territorial belonging or attachment were hardly in evidence.

Outside that realm, though, the new world of the Indies was beginning to loom large, with the confused and confusing experience of epochal change -we call it modernity- impressing itself on the minds of the few. As Cipto remarked, "Without any doubt, the present day Indies is passing through a particularly pregnant period of evolution". ${ }^{31}$ That sense expressed itself in an entirely new conception of belonging; community no longer meant only attachment a specific village, town, city or even ethnic territory, nor to a broad religious solidarity. Now, with the creation of the Netherlands Indies, it involved a consciousness of the new togetherness of nation. The linking of modernity with the sense of the need for urgent reform and an expanded understanding of political place brought the developing realisation that the essential vehicle through which the problems of modernity might be solved was the nation. That was to have serious implications for those of a seriously Muslim bent, because Islamic expressions of consciousness, even the reforming consciousness of the kaum muda, were slow to frame their thinking in terms of a politicoterritorial community. Some, like Ahmad Ripangi in mid-nineteenth century Java, asserted their religious authority in opposition to the operations and policies of an infidel government. ${ }^{32}$ Others, a little later, expressed deep regret that local Muslim disunity had allowed infidel

\footnotetext{
${ }^{30}$ Laffan, Islamic Nationhood, p. 99.

31 Tjipto Mangoenkoesomo, “Geestelijke immobiliteit geeischt," Het Tijdschrift 1 (1912), p. 17.

${ }^{32}$ Laffan, Islamic Nationhood, p. 32.
} 
conquest in the first place. ${ }^{33}$ But it was panislamism, not territorial assertiveness, that remained the focus of Muslim concern, just as it was that of an increasingly suspicious colonial government. ${ }^{34}$

Islam as religion has not often attached itself to notions of place with the religious fixity that has come to underline modern national sensibility. But Indies Muslims were not entirely unconscious of homeland. The Jarra zommunities maintained in Mecca and Cairo by the large and rapidly growing number of pilgrims, disjointed and riven as they were, had a strong sense of Malayo-Muslim identity but, as Laffan remarks, they expressed their "sense of imagined community above all else as a function of Islam". 35 When they began to join place and religion, the latter was always dominant. Slowly, very slowly, the sense of place began to take sharper focus, partly through a developing network of print built upon long traditions of scholarly contact between Southeast Asian students of Islam and the Middle East itself, which took its inspiration from an increasingly restive, politically charged and relatively free religious centre in Cairo, itself increasingly conscious of attachment to homeland (watom). ${ }^{36}$

In that context the Singapore Jariscript journal al-Imam(1906-08), "the first channel of Cairene discourse in the bila "with the first really serious presentation of the Modernist analysis of social, religious and economic issues," 38 began publication under the leadership of Shaykh Muhłmmad T\{kirir bin Jala $\triangleright$ al-Diæ alMinangkabałi $\rightarrow$-Azhari from Bukittingi. Derivative of the Egyptian alManaritself under the editorial hand of Ridł?al-Ima spoke in vague terms of the identity created by the Malay homelands, but without any closer national specificity, and of the Muslim need to progress in tune with modernity's demands. ${ }^{39}$

33 The Sumatran, Ahmad Lampung, paraphrased by Snouck in Laffan, Islamic Nationhood, p. 67.

34 Snouck, “Over Panislamisme,” p. 366; Laffan, Islamic Nationhood, p. 126.

${ }^{35}$ Laffan, Islamic Nationhood, p. 2.

${ }^{36}$ Ibid., pp. 10, 20, 129, 131, 133.

${ }^{37}$ Ibid., p. 148.

38 M.C. Ricklefs, A History of Modern Indonesia since c. 1200, 3rd ed. (Basingstoke: Palgrave, 2001), p. 214.

39 Laffan, Islamic Nationbood, p. 153; Noer, The Modernist Muslim Movement, p. 34; Azyumardi Azra, "The Transmission of al-Manar's Reformism to the Malay- 
But Indonesian Islam's slowly formulating sense of territoriality was already hopelessly behind the game. Around the same time, the popular journal Bintang Hindia had espoused the Netherlands Indies as its special identifying place, Japan's victory over Russia, underlining notions of national or even racial solidarity rather than religious community, had sounded "the new period for the whole East", 40 and within a few years E.F.E. Douwes Dekker and his colleagues in the Indische Partij (IP)(1912) would drive the idea of the nexus of nation and modernity to its logical conclusion: there is an Indies, we are its citizens, and we demand proprietorial control from the foreign government that currently controls it; "we need here a revolution .... Revolution means THE INDIES STOPS BEING A COLONY AND BECOMES A STATE." ${ }^{41}$ The only basis for unity amongst so diverse a collection of peoples was the nation itself; indeed, "social unity is ... only possible where political equality exists among the uniting parts." 42 Religion, then, was peripheral to IP's main concerns and its attitude to religion disinterested; its only religious task, claimed Douwes Dekker, was "to struggle against every expression of sectarianism, to oppose every attempt to nurture religious hatred, and to preach the religion of brotherliness." 43

While place was important for devout Muslims, it was certainly not the all-consuming entity it was for Douwes Dekker and his fellows. If there was, as Laffan claims, a sense that already "the ultimate goal was the independence (Ar. Istiqla of their various lands (tanah)," 44 it was born of a certain frustration that these Muslim lands were under the sway of Dutch and British. "Does all this not make one's heart heavy

Indonesian World: The cases of al-Imam and al-Munir," Studia Islamika 6, 3 (1999), pp. 79-84, 87, 91.

40 Noto Soeroto, "De Eendracht van Indië en Nederland," Indische Vereeniging: Voordracbten en Mededeelingen 5 (1913), p. 3-4.

${ }^{41}$ Quoted in Anon. [D.A. Rinkes], Bescheiden Betreffende de Vereeninging "De Indiche Partij" (Batavia: Landsdrukkerij, 1913), p. 1.

42 E.F.E. Douwes Dekker, Aansluiting Tusschen Blank en Bruin. Rede, Uitgesprokendoor den beer E.F.E. Douwes Dekker in een Openbare Bijeenkomst, Gehouden te Batavia op 12 December 1911 (Batavia: G. Kolff, 1912), p. 13.

43 E.F.E. Douwes Dekker, De Indische Partij: Haar Wezen en haar Doel (Bandung: Fortuna, 1913), p. 25.

${ }^{44}$ Laffan, Islamic Nationhood, p. 157. 
or indeed wound it?,"45 remarked al-Iman in 1906, with the strong implication that loss of territory to these powers was a function of religious negligence. In that sense, as Noer notes, "in the political field, the ideas from the Middle East among the reformists in Indonesia were less influential than those in the basically religious arena."46

That message was continued by al-Imas successor publication, alMuni $>$ (1911-16), "the first Modernist journal in Indonesia", ${ }^{47}$ a Jaæi> fortnightly published in Padang by the Minangkabau reformist Haji Abdullah Ahmad. ${ }^{48}$ Its masthead contained the motto "For the advancement of Islam, knowledge and news".49 "We plan", it proclaimed, "to establish true Islam among the people of our people (bangsa) ... and to show them the way to the field of advancement and the life of the world which will bring us perfection in the next life ... [We aim to bring our people] to the field of love for the homeland and its people ... and the way of love for the community." 50 That bangsa was in the first instance the Minangkabau homeland, an understanding that gradually expanded to include all of the Muslim inhabitants of the Indies. ${ }^{51}$ There was, however, no sense of opposition to Dutch rule, generally seen as sound, efficient and protective of Muslim interests nor, indeed, any sense that the journal prescribed any kind of political activism. ${ }^{52}$

A more specific engagement with territoriality had to await the emergence, then maturity, of the great Java-based mass organisation, Sarekat Islam (SI). In 1916 - the year of SI's first "national congress" (so designated because, SI's leader Cokroaminoto declared, "the popular movement is striving for the formation of a strong unity for all

45 Al-Imarج, vol. 1, no. 3, 19 September 1906, quoted in Laffan, Islamic Nationhood, p. 158.

46 Noer, The Modernist Muslim Movement, p. 299.

47 Ricklefs, $A$ History, p. 214.

48 Noer, The Modernist Muslim Movement, p. 39; Azra, “The transmission,” pp. 92-93.

49 “Adjunct Advisor for Native Affairs (Rinkes) to GG, 19 February 1912," in Van der Wal (ed.), De Opkomst, p. 76.

50 Al-Muni $\gg, 1$ (1 April 1911), quoted in Laffan, Islamic Nationhood, p. 174.

${ }^{51}$ Laffan, Islamic Nationhood, pp. 174-75, 178, 234.

52 Azra, “The transmission," p. 96. 
the people of the Indies Archipelago") ${ }^{53}$ - al-Munis manager, together with Cokroaminoto, founded an al-Islamiyah Association which produced a Jałriptipt journal Al-Isla $\gg$, an "organ for Indies-Muslim nationalists", 54 as its subtitle proclaimed, which explicitly perceived of the nation as "the Muslim people of the Indies". 55

Despite these developments, however, the reformists were still far from centring their attention and core sense of identity on local place; for them it remained at the periphery in a world centred on the Middle East. They saw their task, accordingly, in a typically missionary sense which tended to denigrate the local as derivative and insubstantial, and its improvement as a matter of more assiduous piety, of re-engineering religious belief and practice in such a way that Muslims might no longer suffer the humbling subordination that their religious laxity had visited upon them in the first place.

\section{New Modes of Thinking about Modernity}

While devout Muslims focussed on the demands of reviving and revitalising their faith, entirely new strains of thinking which gave little space to purely Islamic thought were grasping at other Indonesians' minds. The bureaucratic requirements of the developing Dutch colonial state meant that those members of the indigenous elite drawn into Dutch service needed to blend their lifestyles to accord better with Dutch expectations. That included a wariness, and occasionally a fearful paranoia, about the political effects of a more pious, sometimes more militant, profession of Islam, and a general diminution in the importance of Islamic attachment in their lives. ${ }^{56}$ Those in government service, remarked Snouck, "need to know that any form of panislamism is inconsistent with a proper sense of their role or their service". ${ }^{57}$ As Ricklefs remarks, "Only the [form of modernity brought

\footnotetext{
53 Paraphrased in J.Th. Petrus Blumberger, De Nationalistische Beweging in NederlandschIndie (Dordrecht: Foris Publications, 1987 [1931]), p. 63.

${ }^{54}$ Extract in Anon., Sarekat-Islam Congres (1e nationaal congres) 17-24 Juni 1916 te Bandoeng. (behoort bij de Geheime Missive van den wd. Adviseur voor Inlandsche Zaken dd. 29 September 1916 No. 226 (Batavia: Landsdrukkerij, 1916), p. 62.

55 Al-Islarr, 15 June 1916, quoted in Laffan, Islamic Nationhood, p. 179.

56 "Snouck to Director of Education, Worship and Industry, 29 September 1894," in Gobée and Adriaanse (eds), Ambtelijke Adviezen, vol. 3, p. 1991.

${ }^{57}$ C. Snouck Hurgronje, Nederland en de Islam, 2de vermeerde druk (Leiden: E.J. Brill, 1915), p. 69.
} 
by Europeans] offered them also employment, salaries, status and security." 58 Moreover, the indigenous bureaucratic elite had no interest in admitting new competition to their positions of leadership, ${ }^{59}$ sensing the threat presented by the emergence of a middle class of "traders, tradesmen, supervisors ... who continually come to the foreground and take an autonomous position over against the priyayi." 60 Accordingly, Snouck could remark that "the Javanese aristocracy ... as a rule is not strongly Islamic", ${ }^{61}$ and note its "religious tolerance bordering on indifference." 62

The Dutch provided a solidly Western education for their modernising indigenous officials - secular, modern, and embossed with a strong sense of the superiority of Western civilisation and the consequent need for stabilising social hierarchy. This new knowledge, the key to indigenous bureaucratic success, gave them a strong stake in that Westernised world and its continued success; "in our Indonesia", remarked a reminiscing nationalist, "people at the beginning of this century were busy putting out their hands for Western development." ${ }^{63}$ The rise of print in the last decades of the nineteenth century as a medium for the spreading and exchange of information and ideas evoked a cosmopolitanism which itself stimulated elite intellectual curiosity. ${ }^{64}$ Thus, for the musicologist and Theosophist Suryoputro, "the Javanese have taken on the ideal of developing themselves under the guidance of Dutch intellect." 65 Achmad Jayadiningrat, educated in

\footnotetext{
58 Ricklefs, Polarising Javanese Society, p. 127.
}

59 Noer, The Modernist Muslim Movement, p. 209. Noer adds that "in this connection they found ready support from traditionalist ulama ... whose position was also shaken because of the spread of reformist ideas".

${ }^{60}$ M. Lindenborn [Director, Netherlands Missionary Association], Zendingslicht op den Islam (Den Haag: Den Boekhandel van den Zendingstudie Raad, 1918), p. 141.

61 “Snouck to Governor-General, 19 April 1904," in Gobée and Adriaanse (eds), Ambtelijke Adviezen, vol. 1, p. 673 (emphasis in original).

62 Snouck Hurgronje, Nederland en de Islam, p. 87-88.

63 Anon., "Terugblik," in Anon. (ed.), Gedenkboek 1908-1923 Indonesische Vereeniging (n.p.: n.p., n.d [1924]), p. 3.

64 Ahmat B. Adam, The Vernacular Press and the Emergence of Modern Indonesian Consciousness (1855-1913) (Ithaca: Southeast Asia Program, Cornell University, 1995), p. 36.

65 Paraphrased in Anon., "Algemeene vergadering op den 22ste Mei 1915," Indische Vereeniging. Voordrachten en Mededeelingen 10 (1916), p. 54. 
both Western and Islamic traditions but choosing the Western one with subsequent great success, was a manifestation of the way in which Westernisation, increasingly concerned at what it saw as the immobilising and politically dangerous tendencies of the Islam propagated in the Indies, ${ }^{66}$ captured its targets and turned them into humane, cosmopolitan, loyal (though often still Muslim), servants of the status quo. ${ }^{67}$

That sense of distance from any intimate connection with Islam and a corresponding attachment to modern Western thinking was exemplified in the thinking of Raden Ajeng Kartini. She called herself "a child of Buddha", 68 and claimed ignorance of Islam; "in truth, I am a Moslem only because my ancestors were. How can I love a doctrine which I do not know-may never know?" 69 She thought polygamy "an evil of gigantic proportions ... under the protection of Mohammedan teaching." 70 More broadly:

"We have for a long time turned our backs totally against religion because we see so much lovelessness under the banner of religion .... The most beautiful and the most elevated religion we think is: Love. And does one absolutely have to be a Christian to be able to live according to that divine commandment? The Buddhist, the Brahmin, the Jew, the Mohammedan, even the Heathen, can also live a life of love". ${ }^{71}$

Kartini exhibited a kind of open, cultured, faintly liberal humanism rather than any specific attachment to Islamic belief or devotion nor, indeed, any religion as such. Thus, she wrote, "true culture lies not in the colour of the skin, not in the clothes, not in the outward

\footnotetext{
${ }^{66}$ See Snouck, “Over Panislamisme,” pp. 378-79.

${ }^{67}$ Laffan, Islamic Nationhood, pp. 91, 94; Ricklefs, Polarising Javanese Society, pp. 151-53.

68 "Letter to Mrs Abendanon, 27 October 1902," in Joost Coté (trans.), Letters from Kartini: An Indonesian Feminist, 1900-1914 (Clayton: Monash Asia Institute in association with Hyland House, 1992), p. 319.

69 "Kartini to Stella Zeehandelaar, 6 November 1899," in Hildred Geertz (ed.), Letters of a Javanese Princess: Raden Adjeng Kartini (New York: W.W. Norton \& Company, 1964), p. 44.

70 "Letter to Mrs Abendanon, August 1900," in Coté (trans.), Letters from Kartini, p. 26.

71 "Letter to Mrs Abendanon, 27 December 1902," in Coté (trans.), Letters from Kartini, p. 346.
} 
behaviour, not in the language of the speaker, nor in the name of the religion one confesses. True culture resides in the heart. It is a matter of character and nobility of the soul." 72

Such emerging styles of thought gave birth of Budi Utomo (1908), an association which sought, under the inspiration of the modernising journalist Wahidin Sudirohusodo, to refashion Javanese society by combining the best of the (Western) new with (timeless, great, thus pre-Islamic) Javanese culture, itself busily being rediscovered and foregrounded by Dutch scholarship and to create a new sense of identity amongst those broadly construed as belonging to the Javanese cultural heritage. "For the Javanese elite", notes Ricklefs, "Europeanstyle modernity was a means of embracing pre-Islamic culture", 73 itself, indeed, a spiritual and intellectual option to revivalist Islam. ${ }^{74}$ The power of these new styles of thinking and their relation to notions of modernity and progressivity was reflected in the attachment of some members of the aristocratic elite to such currents as Freemasonry and Theosophy. While Freemasonry held little general appeal for Indonesians, Theosophy, with a similar hankering for a kind of synthesised, harmonious human brotherliness that superseded divisions of race and religion, proved rather more attractive to many Javanese aristocrats. One-third of the total membership of the Theosophical Society in the Indies in 1913 comprised "natives", including members of Javanese royal blood; 75 embers also included the Surakarta court physician, Javanese culturalist, and influential BU leader Rajiman, as well as senior SI leaders and Cipto Mangunkusumo.

Indies society was, then, increasingly deeply divided by two separate but interconnected ideological fault lines. On the one hand were the Islamic modernists, the kaum muda, often the products of a Middle Eastern education, spreading their reforming and emancipating religious ideas, over against the traditionalist kaum tua, tied to precedent and tradition, distrustful that change might unbalance society's harmony and enmeshed in cultural constructions of

\footnotetext{
72 "Give the Javanese education!," in Coté (trans.), Letters from Kartini, p. 541.

${ }^{73}$ Ricklefs, Polarising Javanese Society, p. 149.

${ }^{74}$ Ibid., pp. 177, 219.

${ }^{75}$ Herman Arij Oscar de Tollenaere, The Politics of Divine Wisdom: Theosophy and Labour, National, and Womens' Movements in Indonesia and South Asia, 1875-1947 (Nijmegen: Uitgeverij Katholieke Universiteit Nijmegen, 1996), p. 107.
} 
indigenous identity. On the other was the Islamic tradition per se, either modernist or traditionalist, over against a newly emergent secularising tendency which, while often retaining its cultural attachment to Islam, was not ruled by it, was often critical of what it saw as Islam's constraining, conserving tendencies, and sometimes wanted to forget the "Mohammedan" period in Javanese cultural history"; 76 it stretched out to capture and master the new knowledge now increasingly available from the West and to put it at its service.

Its critique of Islam was often expressed in terms of the heights Java had reached in the pre-Islamic period, "the high civilisation ... the high level of industry and art in the pre-Islamic period." 77 For Cipto, the Hindu-Javanese Majapahit era was "the period in our history which lives on in our memory as the golden age of our people", notable for "the already existing tolerance of the Javanese in the arena of belief". The subsequent decline he attributed to the meeting of an aging religion - Islam - with a declining civilisation. ${ }^{78}$ Rajiman spoke of "the glorious period of Majapahit", upon which the "invasion of the Mohammedan religion" had exercised a culturally debilitating effect. ${ }^{79}$ Cipto's brother Gunawan thought that "in many respects the Mohammedan religion displays so little obligingness (inschikkelijkheid) that it ... is inimical to our character." "The Koran is our holy book, we believe in it", he asserted but, he asked, "do we love it? Do we cherish it in our heart as we do Javanese books, which tell us of Majapahit's greatness?" Indeed, "our popular entertainment par excellence, the wayang, is an abomination for the true Islamite", and "no matter how high the cultural value of Islam may be, it can not reach the heart of the people." In the end Gunawan feared the capacity of religion to divide, and that it stood in the way of his country's

\footnotetext{
76 See "Nota over Het Congres voor Javaanse Cultuurontwikkeling van B.J.O Schrieke, 27 juli 1918," in R.C. Kwantes (ed.), De Ontwikkeling van de Nationalistische Beweging in Nederlandsch-Indië vol. 1 (Groningen: H.D. Tjeenk Willink, 1975), p. 66.

77 "Darmo Kondo 6 November 1918," in Overzicht van de Inlandsche en Maleisch-Chineesche Pers [IPO] 45/1918.

78 Tjipto Mangoenkoesoemo, Iets Over den Javaan, Zijn Geschiedenis en Zijn Ethiek (Semarang: n.p., 1913), pp. 5, 6, 11.

79 Radjiman, "De Maatschappelijke Loop van de Javaansche (Indonesische) Bevolking," Indisch Genootschap: vergadering van 27 February 1920, pp. 64, 66; Radjiman, "Het Psychisch Leven van Het Javaansch Volk," Indisch Genootschap: Algemeene Vergadering van 14 February 1911, p. 154.
} 
resurrection should it be employed as a political weapon. ${ }^{80}$ The Javanese nationalist Suriokusumo thought that "religion as a means of unity is finished. Islam can not tie us to the Sumatran, much less to the Ambonese or Menadonese who are not Muslims. Religion as a means of unity is very unwise if not dangerous." 81 An Indonesian writer took the Prophet to task for his "actions against the Jews and his attitude towards his women." 82 The Javanese elitist Satiman Wiryosanjoyo was rather more direct: he saw religious zealotry as inimical to national development, and the pilgrimage as a waste of money. 83

\section{Belated Islamism}

The territorial agnosticism exhibited by Muslim leaders ignored the political implications of the gathering, consolidating unity of the Netherlands Indies. As we have seen, by the early years of the twentieth century some indigenous intellectuals had began to express a sense of Indies identity, of being part of the new state of the Indies, based on a specific sense of territory and with no particular attachment to Islamic thinking. Bintang Hindia spoke of a bangsa Hindia (Indies nation) that needed reform and renovation, and exemplified the notion that the key to advancement was modern knowledge. ${ }^{84}$ Its masthead proclaimed "May the kingdom of the Netherlands endure forever, may the land of the Indies (tanah Hindia) be famous." Its editor, Abdul Rivai, spoke of a time when the native people of Java "would turn their face in prayer no longer to the ka'bah but to The Hague." 85

80 Goenawan Mangoenkoesoemo, "Ons Standpunt Tegenover den Godsdienst," in Anon., Soembangsib: Gedenkboek Boedi-Oetomo: 1908-20 Mei-1918 (Amsterdam: Tijdschrift Nederl. Indië Oud \& Nieuw, 1918), pp. 106, 107, 109, 111.

81 R.M.S. Soeriokoesoemo, "Javaansch Nationalisme," in R.M.S. Soeriokoesoemo, A Muhlenfeld, Tjipto Mangoenkoesoemo, and J.B. Wens, Javaansche of Indisch Nationalisme? Pro en Contra (Semarang: Semarang Drukkerij en Boekhandel H.A. Benjamins, 1918), p. 3-4.

82 De Expres 19 February 1913, quoted in Anon., Vervolg der Nota I, Betreffende de Geschriften van Douwes Dekker (Batavia: Landsdrukkerij, 1913), p. 23.

${ }^{83}$ Petrus Blumberger, De Nationalistische Beweging, p. 198.

${ }^{84}$ Adam, The Vernacular Press, p. 105; Laffan, Islamic Nationhood, p. 99.

85 Quoted in Harry A. Poeze, "Early Indonesian emancipation: Abdul Rivai, Van Heutsz, and the Bintang Hindia," Bijdragen tot de Taal-, Land- en Volkenkunde 145 (1989), p. 91. 
Douwes Dekker's IP concretised and gave intellectual substance sentiments of that kind.

Islam did provide the bases of the first mass political movement in the Indies, SI, but it was a diffuse and shifting foundation. Broadbased but locally-rooted, with a vague egalitarianism which stood in opposition to demeaning aristocratic hierarchy, SI was a "great folk movement which linked Islamic revival with anti-colonialism." 86 It was, in the words of Governor-General Idenburg, "an expression of what can be called the Native becoming self-conscious." 87 It sought social and material welfare and mutual assistance, making an explicit claim for Muslim solidarity in pursuit of those goals, aiming at enhanced religious piety and observance, and devoting itself to the progress and emancipation of the native peoples. ${ }^{88}$ It operated as society's sounding board, its crisis and grievance centre. Islam, indeed, was SI's identifying, communitarian motif, bringing together people of variously different understandings of Islam but -notwithstanding an evident increase in piety, Islamised social behaviour, clubbish solidarity and assertiveness ${ }^{89}$ - not just for specifically Islamic purposes. Sarekat Islam in its early great phase never gave specific prominence to Islamic thought or teaching; 90 Suwardi Suryaningrat, scion of the house of

${ }^{86}$ David E.F. Henley, Nationalism and Regionalism in a Colonial Context: Minahasa in the Dutch East Indies (Leiden: KITLV Press, 1996), pp. 84-85.

87 "Governor-General to Minister of Colonies, 2 July 1913," Archive of the Minster of Colonies [AMK], Exhibitum 31 July 1913/U22, Verbaal [V] 9 August 1913/B13, Nationaal Archief, The Hague [NADH].

88 See, for example, "Secret Nota Bupati Rembang to Resident Rembang, 13 April 1913," "Assistant-Resident Tangerang to Resident Batavia, 7 May 1913," "Resident Surakarta to Governor-General, 24 May 1913," in Sartono Kartodirdjo et al. (eds), Sarekat Islam Lokal (Jakarta: Arsip Nasional Republik Indonesia, 1975), pp. 13, 190, 339.

89 "Adjunct Advisor for Native Affairs [Rinkes] to Governor-General, 13 May 1913," "Advisor for Native Affairs [Rinkes] to Governor-General, 30 November 1915," both in Van der Wal (ed.), De Opkomst, p. 201-02, 430; "Letter Official assisting AttorneyGeneral (Hoorweg) to Attorney General, 3 February 1919,” AMK, Mail report [MR] 1358/1919, NADH; "Assistant Resident Meester-Cornelis to Resident Batavia, 26 July 1914," in Kartodirdjo et al. (eds), Sarekat Islam Lokal, p. 48.

90 Bernhard Dahm, Sukarno and the Struggle for Indonesian Independence (Ithaca: Cornell University Press, 1969), p. 174; Harry A. Poeze, "Inleiding," in Harry A. Poeze (ed.), Politiek-politioneele overzichten van Nederlandsche-Indië vol. 1 (The Hague: Martinus Nijhoff, 1982), p. xxx. 
Paku Alam, sought in 1913 to remove the requirement that SI members be Muslims because the real solidarity needing expression was that of the inhabitants of the Indies, a spatial rather than religious tie. ${ }^{91}$

Although being Muslim was framed as the badge of indigeneity, SI originally had no overt political agenda. Cokroaminoto asserted in 1912 that "according to the Sjari'ah of Islam, we must obey the command of the Dutch government, we must strictly and loyally follow the laws and regulations of the Dutch." 92 Nonetheless, SI's astonishingly rapid growth and its size and weight necessitated, soon enough, that it engage in politics frontally. In doing so, however, it found itself inevitably drawn into nationalist politics, the framing of indigenous improvement in relation to enhanced political autonomy. As Suwardi pointed out, SI had decided "in future to accept not only religion but also and especially Indies nationalism as the bond of unity." 93 SI leader Abdul Muis remarked in 1917 that "the basis of our movement ... is nationalist." ${ }^{94}$ SI embraced the idea of representational politics ("the administration of the Indies by its own people, without there being any discrimination on the basis of race, colour or religion"), ${ }^{95}$ as well as strains of socialism, even as it proclaimed that Islam was "the religion par excellence for the moral education of the people". ${ }^{96}$ For the formidable SI intellectual, Haji Agus Salim, the connection between religion and politics remained one essentially of enhanced private behaviour for the social good. Cokroaminoto thought likewise: "Currently many bad usages and customs dominate amongst us, while we do not give enough of our attention to religious matters. We always feel ourselves of lesser worth and are convinced of

\footnotetext{
${ }^{11}$ Shiraishi, An Age in Motion, p. 59.

92 Oetoesan Hindia, 24 March 1912, quoted in Noer, The Modernist Muslim Movement, pp. 111-12.

${ }^{93}$ Surya Ningrat [Suwardi Suryaningrat], "Het Javaansch nationalisme in de Indische beweging," in Anon., Soembangsih, p. 33.

94 Abdoel Moeis, "Hindia boeat anak Hindia" [1917], in Pitut Soeharto and A. Zainoel Ihsan (eds.), Permata Terbenam; Capita Selecta Keempat (Jakarta: Aksara Jayasakti, 1982), p. 74.

${ }^{95}$ Paraphrased in Anon., Sarekat-Islam Congres (2e Nationaal Congres) 20-27 October 1917 te Batavia (Batavia: Landsdrukkerij, 1919), p. 2.

96 "Beginselverklaring en werkprogramma," Bijlage IV of ibid., p. 103.
} 
our weakness. This has to change, and it shall, if we truly know the teaching of our religion and carry it out." 97

SI had become political, but not (yet) Islamist. In taking up the nationalist discourse, SI would face three great problems. The first was the blowtorch of increasing government opposition. The second was a test of its Muslim credentials. The third was the enduring problem of maintaining the centrality of Islam in a multicultural/multireligious society.

As government suspicion of SI's political pretensions grew -fuelled by reports of SI-sponsored violence and intrigueconservative members fell away. Many Hadramis, previously highly prominent in the organisation, but discouraged by growing leftism and reports of systematic corruption, and increasingly marginalised because of their lack of "nativeness", took their leave, ${ }^{98}$ as did other "quiet, settled citizens of native society." 99

A challenge from the developing Communist movement came in the form of a purely tactical move that aimed to capture SI and move in a more radical, politically purposeful direction. That stimulated a reaction, an effort by more self-consciously Islamic forces within SI, centred around Salim and the invigorated Yogyakarta branch of SI, to push the movement along more determinedly Muslim lines as a hedge against Communist influence spearheaded from Semarang. ${ }^{100}$ In this Muslim turn, the role of Salim, whose earlier experience as an employee at the Netherlands' consulate in Jeddah (1906-11) had brought him religious revivification as well as a close relationship with

97 Paraphrased in "Meeting over den Mohammedaanschen godsdienst in het Sirenepark (Vrijdag 25 October 1917," Bijlage VI of ibid., p. 115.

98 Mobini-Kesheh, The Hadrami Awakening, pp. 33, 46, 48, 50-51; "Snouck to Governor-General, 19 April 1904," in Gobée and Adriaanse (eds), Ambtelijke Adviezen, vol. 1, p. 671.

99 “Overzicht van den inwendigen politieken toestand [1922]," AMK, MR 141*/1923, NADH.

100 It is interesting that the Yogyakarta group included Suryopranoto, the famous "strike king" and leader of the sugar factory workers' union, the Personeel Fabrieks Bond, who was not noted as a fierce champion of religion. Indeed, a report of PFB congress of 1 January 1921 contained not a single direct mention of religion, let alone Islam, and the aims of the PFB included no mention of religion ("Congres P.F.B. gehouden ten huize van Karijoredjo, Toego koelon, op den 31 Dec. 1920 and 1 Januari 1921," AMK, MR 360*/1921, NADH; "Wd Aviseur voor Inlandsche Zaken (R.Kern) to Governor-General, 22 September 1920," AMK, MR1248*/1920, NADH). 
'Abduhist thinking, ${ }^{101}$ became ever more important, and Cokroaminoto's ever more that of figurehead. Salim, with his knowledge of Arabic and his Middle Eastern experience, enjoyed much greater authority in his Islamic discourse than did Cokroaminoto, whose Islam was partly learned from English-language books since he knew little Arabic.102 It was, in the end, Salim "who gave an Islamic stamp to the political character of the Sarekat Islam". ${ }^{103}$ It was now becoming clear that Islam, under Salim's guiding hand, was to be the driver of SI's policy and politics in a way that had never been evident before. ${ }^{104}$ That position had the virtue of excluding communists (achieved by virtue of the imposition of party discipline in 1921), emphasising Islam as the bond of all Indonesians, and containing the essential elements, economic, social, and spiritual, for Indonesia's uplift. ${ }^{105}$

Salim was the first Muslim politician who attempted explicitly and systematically to relate his Islam ("Islam provides a perfect compass and road-map for humanity for its life in the world") ${ }^{106}$ to the political problems facing his country and people. It was he who "brought the colour of Islam to SI". ${ }^{107}$ Hitherto, Islamic thinking had generally been of a single-dimensional quality, the process of determining how specific issues might be understood - better, adjudicated- from an Islamic perspective. Salim sought to develop from Islam a political

${ }^{101}$ De Tollenaere, The Politics of Divine Wisdom, p. 165; Erni Haryanti Kahfi, "Haji Agus Salim: His Role in Nationalist Movements in Indonesia during the Early Twentieth Century" (Unpublished MA dissertation, McGill University, 1996), p. 22.

102 Hasnul Arifin Melayu, "Islam as An Ideology: The Political Thought of Tjokroaminoto," Studia Islamika 9, 3 (2002), p. 54.

103 Noer, The Modernist Muslim Movement, p. 298.

104 Melayu, "Islam as an ideology," p. 58.

105 See Ruth T. McVey, The Rise of Indonesian Communism (Ithaca: Cornell University Press, 1965), p. 100.

106 Dunia Islam, 23 March 1923, in Panitia Peringatan Hadji A. Salim Genap Berusia 70 Tahun [Mohamad Roem et al.], Djedjak Langkah Hadji A. Salim: Pilihan Karangan, Utjapan dan Pendapat Beliau dari Dulu sampai Sekarang (Jakarta: Tintamas, 1954), p. 4.

107 Suradi, Haji Agus Salim dan Konflik Politik dalam Sarekat Islam (Jakarta: Pustaka Sinar Harapan, 1997), p. 54. 
approach of a general kind. ${ }^{108}$ For him, "there is no need to look for other 'isms' to treat the sickness of the movement. The medicine is in the foundation itself, a foundation which is ancient and enduring ... that foundation is Islam." 109 Thus, the basic principles he drafted for SI included the conviction that "genuine freedom for the people of the Indies, that is, what will really release all the people from every kind of subjection, is by means of the road to freedom based upon Islam." 110 For Salim, "all virtues of the other principles can be found in Islam while all defects, faults and evils of the other principles are absent in Islam."111

That intellectual trajectory had its natural conclusion in the holding of the first Al-Islam congress in Cirebon late in 1922 which marked Cokroaminoto's move from leading a catholic movement of progress and protest to a more narrowly confined emphasis on Islam and the unity which Islam brought. ${ }^{112}$ Cokroaminoto himself, as well as focussing on Islamic morality - "the necessity that Islam become a living force in people, so that they become better people inside" 113 began further to develop his thinking on the relationship of Islam to socialism. ${ }^{114}$ That thinking sought to find in the Qur'a principles of equality and brotherhood, as well as opposition to the rapacity of capitalism. ${ }^{115}$ Around the same time came the slowly gestated emergence of the Partai Sarekat Islam (PSI), ${ }^{116}$ an organisational overhaul of SI that formally recognised the reality and centrality of contestation for the territory of the Indies (now increasingly called

108 Th. Sumartana, Mission at the Crossroads: Indigenous Churches, European Missionaries, Islamic Association and Socio-religious Change in Java 1812-1936 Jakarta: BPK Gunung Mulia, 1994), p. 219.

109 Neratja, 18 October 1921, quoted in Suradi, Haji Agus Salim, p. 42.

${ }^{110}$ HA Salim, Neratja, 18 October 1921, quoted in Suradi, Haji Agus Salim, p. 54.

111 HA Salim, Neratja, 18 October 1921, quoted in Noer, The Modernist Muslim Movement, p. 124.

112 Shiraishi, An Age in Motion, p. 237.

113 Cokroaminoto's paraphrased remarks in "Verslag van het 2e al-Islam-Hindia Congres gehouden te Garoet van 19-21 Mei 1924," AMK, MR 460*/1924, NADH.

${ }^{114} \mathrm{McVey}$, The rise of Indonesian Communism, pp. 141-42.

115 Paraphrased remarks of Cokroaminoto in "Verslag van het 2e al-Islam-Hindia Congres".

116 "Overzicht van den inwendigen politieken toestand [1922]". 
Indonesia) and at the same time a vehicle of panislamic pretensions (even is these were essentially directed towards domestic purposes of Islamic solidarity-making). ${ }^{117}$ PSI sought to represent in a more disciplined and controlled way devout Muslim political interests rather than, as SI had done, bridging a multiplicity of interests.

Many SI members were dismayed at SI's conversion into a deeply religiously-grounded political organisation. ${ }^{118}$ One East Java member thought that "as soon as politics and religion separate from each other, the SI shall undoubtedly progress and unity can quickly be organised."119 Kaum tua supporters saw themselves increasingly marginalised and exposed and sought to improve their status by establishing a rival association in 1926, traditionalist in orientation but modern in its methods and pragmatically flexible in its political practice. ${ }^{120}$ Even Muhammadiyah found itself a victim of PSI party discipline, something caused by Muhammadiyah's view that "those who use religion for political purposes are infidels"121 as well as its developing competition with PSI, ${ }^{122}$ and reflecting Muhammadiyah's disdain for PSI's increasingly isolationist and combative approach. Other critics, especially Communists, saw the defining Islamist turn as a rejection and a retreat from the task of opposition and confrontation; "in the practical politics of the far left wing Islam plays no role." 123

117 "Politiek Politioneel Overzicht [PPO] March 1927," in Poeze (ed.), Politiekpolitioneele Overzichten, p. 24. See also "Snouck to Minister of Colonies, 2 February 1926," in Gobée and Adriaanse (eds), Ambtelijke Adviezen, vol. 2, p. 1716; Suradi, Haji Agus Salim, p. 41.

118 McVey, The rise of Indonesian Communism, pp. 166-67.

119 Kemadjoean Hindia, 5-11 December 1925, IPO 51/1925. For comments of a similarly critical kind, see also PPO June 1927, PPO November 1927, PPO December 1927, all in Poeze (ed.), Politiek-politioneele Overzichten, pp. 68, 174, 197.

${ }^{120}$ Laffan, Islamic Nationhood, p. 235; Giora Eliraz, "The Islamic Reformist Movement in the Malay-Indonesian World in the First Four Decades of the 20th Century: Insights Gained from a Comparative Look at Egypt," Studia Islamika 9, 2 (2002), p. 68.

121 SI leader Sastroatmojo, quoted in "Neutraliseering en bestrijding van revolutionnaire propaganda onder de inheemsche bevolking, in het bijzonder van Java en Madoera," AMK, MR 457*/1928, V 1 May 1929 C9, NADH. See also Noer, The Modernist Muslim Movement, pp. 137, 235-37.

122 Abdullah, Schools and Politics, p. 156.

123 "Overzicht van den inwendigen politieken toestand [1922]". See also Shiraishi, $A n$ Age in Motion, p. 245. 
RE Elson

At the same time there emerged a florescence of national consciousness that trenchantly focussed on the national, on national identity and culture, and on national deliverance from foreign domination, and in which Islamically-tinged ideas had little traction. The young Sukarno, though he had lived in Cokroaminoto's house for many years and married his daughter, had clearly opted not to ally himself with the revised SI and under the influence of secularists like Cipto had, in the words of a Dutch official, "let Islam go". ${ }^{124}$ In the Netherlands, a small, vigorous and increasingly radically-minded group of young Indonesian students was creating an unambiguous sense of a new nation, Indonesia, and the fact that it must be granted - or seizeits freedom. It is arresting to recognise that as one leaves through the pages of its journals Hindia Poetra and later Indonesia Merdeka, one finds scarcely any mention of Islam. By contrast, while Indies students in Cairo, conscious of anti-British political action in Egypt, ${ }^{125}$ could move relatively easily to a sense of the freedom of their own homeland, theirs was a distinctly muted, derivative and still strangely vague and now dated sense of pan-Malay Islamic identity. ${ }^{126}$

Not for the first and not for the last time, Islam was travelling in directions different from those taken by those who had accepted the supremacy of the idea of Indonesia. Cipto was characteristically blunt; after its split with the Communists, SI "threw itself on Islam, promoting the interests of which it made its single goal. Thereby it is chained to the great world Islam movement, centred on Arabia and or Egypt." 127 SI was increasingly embracing exclusivity. A leader of the Bangil branch remarked in 1923 that "an organisation based on Islam may not mix with non-Muslim associations." 128 Salim made the same point when he remarked that PSI was "independent of any other

\footnotetext{
124 "Report Ch. O van der Plas, September 1927/March 1928," in Kwantes (ed.), De Ontwikkeling vol. 2 (Groningen: Wolters-Noordhof, 1978), p. 715.

125 "Consul at Jeddah to Minister of External Affairs, 15 December 1928," AMK, MR 113*/1929, V 23 April 1929/N8, NADH.

126 Laffan, Islamic Nationhood, pp. 220-21, 234. For correspondence between Perhimpunan Indonesia in the Netherlands and Cairo students, see AMK, V 9 August 1927/G13, NADH.

127 Tjipto Mangoenkoesoemo, Het Communisme in Indonesië: naar Aanleiding van de Relletjes (Bandung: Algemeene Studieclub, 1927), p. 13.
}

128 Oetoesan Hindia 9-15 January 1923, IPO 3/1923. 
association or body", ${ }^{129}$ something also evident in his later suspicion of Sukarno's federation of political parties, PPPKI. ${ }^{130}$ The claim aired at one PSI meeting - "as soon is freedom is attained no one shall be named Regent who is not a good Muslim"- might have been calculated to create enmity and opposition. ${ }^{131}$ Laffan is certainly overstating his case when he remarks that "the seeds of what would become Indonesian nationalism germinated in two of the Central Lands of Islam [Mecca and Cairo] as much as in Leiden and Batavia."132 Islam was always and increasingly marginal to developing Indonesian thinking about the national, something exemplified by the emergence of doctrinaire leaders like Persis's Haji Hasan. ${ }^{133}$ The idea of Indonesia, as it emerged, had almost nothing to do with Islam, which provided little more than a vague incipient sense of solidarity in some places, and its opposite in others.

The idea of Indonesia stood for nothing more than a free, united Indonesian nation, based upon the central pillar of popular sovereignty manifested in a "form of government which is responsible to the people in the true sense of the word." 134 That idea subordinated everything else to its service. Its champions frequently derided Islam as being opposed to modernity and progress and serving only partial or sectional interests rather than those of the nation as a whole. Gatot Mangkupraja thought that "in our struggle towards the freedom of Country and Nation, we nationalists do not wished to be caught up in disputes relating to religion." 135 Gradually through the 1920s, association based on ethnic or regional affiliation was forced to cede centrality to the increasingly dominant idea of Indonesia. ${ }^{136}$ Religion

129 Quoted in "Verslag van wd. adviseur voor inlandsche zaken (E. Gobée) van het 14e P.S.I.-congres te Pekalongan, 28 sept.-2 okt. 1927”, in Kwantes (ed.), De Ontwikkeling, vol. 2, p. 619.

130 “PPO December 1928," in Poeze (ed.), Politiek-politioneele Overzichten, p. 490.

131 “PPO July 1927," in Poeze (ed.), Politiek-politioneele Overzichten, p. 84.

132 Laffan, Islamic Nationhood, p. 2.

133 Saleh, Modern Trends in Islamic Theological Discourse, pp. 137-38.

134 "Beginselverklaring en Werkprogram" [Kusuma Sumantri's speech on becoming chairman PI, 1923]," AMK, V 9 August 1927-G13, NADH.

135 Gatot Mangkoepradja, "Kebangsaan Indonesia" [1932], in Soeharto and Ihsan (eds.), Permata Terbenam, p. 297.

136 See, for example, Petrus Blumberger, De Nationalistische Beweging, pp. 298, 299. 
suffered the same fate. The fact that much of the debate about Indonesian identity went to matters of race - for example, Hatta's idea that "nativeness" rested upon ethnicity ${ }^{137}$ - rather than religion was indicative of Islam's weak political power. Within that new nation, Islam should have no more or no less an important role than any other religion. That ruling sense was captured as well in the deeply-felt notion, itself anti-Islamic in fact if not in intention, that Indonesia had always existed, that Islam was just only of many external influences continually reshaping that Indonesia, and that modern nationalism was simply a natural awakening from a long sleep. ${ }^{138}$

\section{Conclusion}

For concluding remarks, I would say that by the early and mid1920s, SI/PSI had become just one of many parties, and its reach and influence were in serious ebb, especially outside Java. ${ }^{139}$ The general impression given by reports on its status was one of declining morale, lack of funds, mistrust of leaders and sagging membership. ${ }^{140}$ It had definitively admitted the decisive power of the idea of Indonesia, but not the cluster of populist, pluralist, inclusivist ideas that underpinned it. In Cokroaminoto's view, nationalism needed to be based upon the unifying power of Islam, which carried none of the divisive baggage of race, status and region-ignoring the fact that Islamism itself was a wedge against true national unity. "We strive", he said, "for the salvation of Indonesia, if possible of all of its people." ${ }^{141}$ Salim was himself even more explicit. While he asserted that "denying nationalism ... is certainly not Islamic," 142 and that "the nationalism of

137 "Hatta to Soejadi, 2 March 1926," AMK, V 9 August 1927-G13, NADH.

138 See, for example, Moehammad Jamin, "Bangsa dan kebangsaan" [1931], in Soeharto and Ihsan (eds.), Permata Terbenam, p. 259.

139 "Overzicht van den inwendigen politieken toestand [1922]". See also Shiraishi, $A n$ Age in Motion, pp. 243, 245; McVey, The rise of Indonesian Communism, p. 166, 177.

140 "PPO July 1928," "PPO September 1928," “PPO November 1928," “PPO December 1928," all in Poeze (ed.), Politiek-politioneele Overizichten, pp. 361, 418, 472, 498 141 "Verslag van de wd. Adviseur voor Inlandsche Zaken (R.A. Kern) van het 11e congres van de Centrale Sarekat Islam te Soerabaja, 8-10 aug. 1924," in Kwantes (ed.), De Ontwikkeling, vol. 2, p. 194.

142 Het Licht, 1, 2 (March 1926), in Panitia, Djedjak Langkah Hadji A. Salim, pp. 98-99. 
the Muslim neither divides nor excludes," 143 he saw Islam as "our national religion, which is certainly not the least factor in our common Indonesian national culture."144 In the end, Islam was supreme; the real problem with colonialism was that "people cannot properly confess Islam, as long as they are still governed by a non-Muslim Government." 145 To govern the state, Salim proposed at a congress in Yogyakarta in early 1928 an "Islamic democracy" that was not "the Western one of half plus one, but this, that those who are capable and inclined to carry on the tasks of the state must have the opportunity and the power for it." 146 In all of this Salim was keen to oppose what he saw as the heresy of the worship of nation (kebangsaan) above all else. "Our love for the people causes us to honour and respect our fellow-countrymen but it will not elevate kebangsaan to an idol to be worshipped and adored." 147 Islamic democracy, by contrast, was the work of the people's representatives, themselves imbued with Islamic principles. ${ }^{148}$

By the end of the 1920s, the dominant political paradigm was inescapably that of the totalising Indonesian nation-state. Muslim politicians, too, had fallen under its power, and had to begin to contrive ways in which they could better accommodate their religious sensibilities under its umbrella. They sought them in a self-defeating emphasis on independent religious specificity in a context where national, not religious, unity had become the dominant currency. The problem for Indonesian Islamists, late to the table, was that they had no hope of popularising their ideals in a context where the nation, and not religion, was sovereign.]

\footnotetext{
143 Quoted in "Verslag van wd. Adviseur voor Inlandsche Zaken (E. Gobée) van het 14e P.S.I.-congres te Pekalongan, 28 sept.-2 okt. 1927," in Kwantes (ed.), De Ontwikkeling, vol. 2, p. 623.

144 Het Licht, 1, 2 (March 1926), p. 102

145 "Sentiment attributed to PSI leaders in Attorney-General (H.G.P. Duyfjes) to Governor-General, 28 October 1927," in Kwantes (ed.), De Ontwikkeling, vol. 2, p. 641.

146 Quoted in report Ch. O van der Plas, September 1927/March 1928, in Kwantes (ed.), De Ontwikkeling, vol. 2, pp. 724-25.

147 H.A. Salim, Hindia Baru, 10 May 1925, quoted in Noer, The Modernist Muslim Movement, p. 254.

148 Melayu, "Islam as An Ideology”, p. 67.
} 
RE Elson

\section{Bibliography}

"Adjunct Advisor for Native Affairs (Rinkes) to GG, 19 February 1912," in Van der Wal (ed.). De Opkomst van de Nationalistische Beweging in Nederlandsche-Indie. Groningen: J.B. Wolters, 1967: 76.

"Adjunct Advisor for Native affairs [Rinkes] to Governor-General, 13 May 1913," in S.L. van der Wal (ed.). De Opkomst van de Nationalistische Beweging in Nederlandsche-Indie. Groningen: J.B. Wolters, 1967.

"Adjunct Advisor for Native Affairs [Rinkes] to Governor-General, 13 May 1913," in Van der Wal (ed.). De Opkomst van de Nationalistische Beweging in Nederlandsche-Indie. Groningen: J.B. Wolters, 1967: 201-02.

"Advisor for Native Affairs [Rinkes] to Governor-General, 30 November 1915," in Van der Wal (ed.). De Opkomst van de Nationalistische Beweging in Nederlandsche-Indie. Groningen: J.B. Wolters, 1967: 430.

"Assistant Resident Meester-Cornelis to Resident Batavia, 26 July 1914," in Kartodirdjo et al. (eds), Sarekat Islam Lokal. Jakarta: Arsip Nasional Republik Indonesia, 1975: 48.

"Assistant-Resident Tangerang to Resident Batavia, 7 May 1913," in Sartono Kartodirdjo et al. (eds). Sarekat Islam Lokal. Jakarta: Arsip Nasional Republik Indonesia, 1975: 190.

"Beginselverklaring en Werkprogram" [Kusuma Sumantri's speech on becoming chairman PI, 1923]," AMK, V 9 August 1927-G13, $\mathrm{NADH}$.

"Beginselverklaring en werkprogramma." Bijlage IV of Anon. SarekatIslam Congres (2e Nationaal Congres) 20-27 October 1917 te Batavia. Batavia: Landsdrukkerij, 1919: 103.

"Congres P.F.B. gehouden ten huize van Karijoredjo, Toego koelon, op den 31 Dec. 1920 and 1 Januari 1921," AMK, MR 360*/1921, NADH.

"Consul at Jeddah to Minister of External Affairs, 15 December 1928," AMK, MR 113*/1929, V 23 April 1929/N8, NADH.

"Darmo Kondo 6 November 1918," in Overzicht van de Inlandsche en Maleisch-Chineesche Pers [IPO] 45/1918. 
"Give the Javanese education!," in Joost Coté (trans.). Letters from Kartini: An Indonesian Feminist, 1900-1914. Clayton: Monash Asia Institute in association with Hyland House, 1992: 541.

"Governor-General to Minister of Colonies, 2 July 1913," Archive of the Minster of Colonies [AMK], Exhibitum 31 July 1913/U22, Verbaal [V] 9 August 1913/B13, Nationaal Archief, The Hague [NADH].

"Hatta to Soejadi, 2 March 1926," AMK, V 9 August 1927-G13, $\mathrm{NADH}$.

"Kartini to Stella Zeehandelaar, 6 November 1899," in Hildred Geertz (ed.). Letters of a Javanese Princess: Raden Adjeng Kartini. New York: W.W. Norton \& Company, 1964: 44.

"Letter Official assisting Attorney-General (Hoorweg) to Attorney General, 3 February 1919," AMK, Mail report [MR] 1358/1919, $\mathrm{NADH}$.

“Letter to Mrs Abendanon, 27 December 1902," in Joost Coté (trans.). Letters from Kartini: An Indonesian Feminist, 1900-1914. Clayton: Monash Asia Institute in association with Hyland House, 1992: 346.

"Letter to Mrs Abendanon, 27 October 1902," in Joost Coté (trans.). Letters from Kartini: An Indonesian Feminist, 1900-1914. Clayton: Monash Asia Institute in association with Hyland House, 1992: 319.

"Letter to Mrs Abendanon, August 1900," in Joost Coté (trans.). Letters from Kartini: An Indonesian Feminist, 1900-1914. Clayton: Monash Asia Institute in association with Hyland House, 1992: 26.

"Meeting over den Mohammedaanschen godsdienst in het Sirenepark (Vrijdag 25 October 1917." Bijlage VI of Anon. Sarekat-Islam Congres (2e Nationaal Congres) 20-27 October 1917 te Batavia. Batavia: Landsdrukkerij, 1919: 115.

"Neutraliseering en bestrijding van revolutionnaire propaganda onder de inheemsche bevolking, in het bijzonder van Java en Madoera," AMK, MR 457*/1928, V 1 May 1929 C9, NADH.

"Nota over Het Congres voor Javaanse Cultuurontwikkeling van B.J.O Schrieke, 27 juli 1918," in R.C. Kwantes (ed.). De Ontwikkeling 
RE Elson

van de Nationalistische Beweging in Nederlandsch-Indië vol. 1. Groningen: H.D. Tjeenk Willink, 1975: 66.

"Overzicht van den inwendigen politieken toestand [1922]", AMK, MR 141*/1923, NADH.

“Politiek Politioneel Overzicht [PPO] March 1927," in Harry A. Poeze (ed.). Politiek-politioneele overzichten van Nederlandsche-Indië vol. 1. The Hague: Martinus Nijhoff, 1982: 24.

"Report Ch. O van der Plas, September 1927/March 1928," in Kwantes (ed.). De Ontwikkeling vol. 2. Groningen: WoltersNoordhof, 1978: 715.

"Resident Surakarta to Governor-General, 24 May 1913," in Sartono Kartodirdjo et al. (eds). Sarekat Islam Lokal. Jakarta: Arsip Nasional Republik Indonesia, 1975: 339.

"Secret Nota Bupati Rembang to Resident Rembang, 13 April 1913," in Sartono Kartodirdjo et al. (eds). Sarekat Islam Lokal. Jakarta: Arsip Nasional Republik Indonesia, 1975: 13.

"Sentiment attributed to PSI leaders in Attorney-General (H.G.P. Duyfjes) to Governor-General, 28 October 1927," in Kwantes (ed.). De Ontwikkeling vol. 2. Groningen: Wolters-Noordhof, 1978: 641.

"Snouck to Directeur of Education, Worship and Industry, 21 March 1892," in Gobée and Adriaanse (eds). Ambtelijke Adviezen van C. Snouck Hurgronje 1889-1936. The Hague: Martinus Nijhoff, 195765. vol. 2: 1077.

"Snouck to Director of Education, Worship and Industry, 29 September 1894," in Gobée and Adriaanse (eds), Ambtelijke Adviezen van C. Snouck Hurgronje 1889-1936. The Hague: Martinus Nijhoff, 1957-65. vol. 3: 1846-48.

"Snouck to Director of Education, Worship and Industry, 29 September 1894," in Gobée and Adriaanse (eds). Ambtelijke Adviezen van C. Snouck Hurgronje 1889-1936. The Hague: Martinus Nijhoff, 1957-65. vol. 3: 1991.

"Snouck to Director van of Education, Worship and Industry, 16 October 1894," in Gobée and Adriaanse (eds). Ambtelijke Adviezen van C. Snouck Hurgronje 1889-1936. The Hague: Martinus Nijhoff, 1957-65. vol. 2: 1080. 
"Snouck to Governor-General, 19 April 1904," in Gobée and Adriaanse (eds), Ambtelijke Adviezen van C. Snouck Hurgronje 18891936. The Hague: Martinus Nijhoff, 1957-65. vol. 1: 673 (emphasis in original).

"Snouck to Governor-General, 19 April 1904," in Gobée and Adriaanse (eds). Ambtelijke Adviezen van C. Snouck Hurgronje 18891936. The Hague: Martinus Nijhoff, 1957-65. vol. 1: 671.

"Snouck to Minister of Colonies, 2 February 1926," in Gobée and Adriaanse (eds). Ambtelijke Adviezen van C. Snouck Hurgronje 18891936. The Hague: Martinus Nijhoff, 1957-65. vol. 2: 1716

"Snouck to Minister of Colonies, 28 October 1910," in Gobée and Adriaanse (eds), Ambtelijke Adviezen van C. Snouck Hurgronje 18891936. The Hague: Martinus Nijhoff, 1957-65. vol. 2: 1099.

"Verslag van de wd. Adviseur voor Inlandsche Zaken (R.A. Kern) van het 11e congres van de Centrale Sarekat Islam te Soerabaja, 8-10 aug. 1924," in Kwantes (ed.). De Ontwikkeling vol. 2. Groningen: Wolters-Noordhof, 1978: 194.

"Verslag van het 2e al-Islam-Hindia Congres gehouden te Garoet van 19-21 Mei 1924," AMK, MR 460*/1924, NADH.

"Verslag van wd. adviseur voor inlandsche zaken (E. Gobée) van het 14e P.S.I.-congres te Pekalongan, 28 sept.-2 okt. 1927', in Kwantes (ed.). De Ontwikkeling vol. 2. Groningen: WoltersNoordhof, 1978: 619.

"Verslag van wd. Adviseur voor Inlandsche Zaken (E. Gobée) van het 14e P.S.I.-congres te Pekalongan, 28 sept.-2 okt. 1927," in Kwantes (ed.). De Ontwikkeling vol. 2. Groningen: WoltersNoordhof, 1978: 623.

"Wd Aviseur voor Inlandsche Zaken (R.Kern) to Governor-General, 22 September 1920," AMK, MR1248*/1920, NADH.

Abdullah, Taufik. Schools and Politics: The Kaum Muda Movement in West Sumatra (1927-1933). Ithaca: Cornell Modern Indonesia Project, Cornell University, 1971.

Abushouk, Ahmed Ibrahim. "A Sudanese Scholar in the Diaspora: Life and Career of Ahmad Muhamad al-Surkitti in Indonesia (19111943)." Studia Islamika 8, 1 (2001). 
RE Elson

Adam, Ahmat B. The Vernacular Press and the Emergence of Modern Indonesian Consciousness (1855-1913). Ithaca: Southeast Asia Program, Cornell University, 1995.

AMK, V 9 August 1927/G13, NADH.

Anon. [D.A. Rinkes]. Bescheiden Betreffende de Vereeninging "De Indiche Partij”. Batavia: Landsdrukkerij, 1913.

Anon. "Algemeene vergadering op den 22ste Mei 1915." Indische Vereeniging. Voordrachten en Mededeelingen 10 (1916: 54.

Anon. "Terugblik," in Anon. (ed.). Gedenkboek 1908-1923 Indonesische Vereeniging. n.p.: n.p., n.d [1924]: 3.

Anon. Sarekat-Islam Congres (1e nationaal congres) 17-24 Juni 1916 te Bandoeng. (behoort bij de Geheime Missive van den wd. Adviseur voor Inlandsche Zaken dd. 29 September 1916 No. 226. Batavia: Landsdrukkerij, 1916.

Anon. Sarekat-Islam Congres (2e Nationaal Congres) 20-27 October 1917 te Batavia. Batavia: Landsdrukkerij, 1919.

Anon. Vervolg der Nota I, Betreffende de Geschriften van Douwes Dek.ker. Batavia: Landsdrukkerij, 1913.

Azra, Azyumardi. "The Transmission of al-Manar's Reformism to the Malay-Indonesian World: The cases of al-Imam and al-Munir." Studia Islamika 6, 3 (1999).

Blumberger, J.Th. Petrus. De Nationalistische Beweging in NederlandschIndie. Dordrecht: Foris Publications, 1987 [1931].

Boeka [P.C.C. Hansen Jr]. "De Inlander, Een Studie." De Indische Gids 25 (1903): 1137.

Bowen, John R. Muslims through Discourse: Religion and Ritual in Gayo Society. New Jersey: Princeton University Press, 1993.

Dahm, Bernhard. Sukarno and the Struggle for Indonesian Independence. Ithaca: Cornell University Press, 1969.

Dekker, E.F.E. Douwes. Aansluiting Tusschen Blank en Bruin. Rede, Uitgesprokendoor den heer E.F.E. Dounes Dekker in een Openbare Bijeenkomst, Gehouden te Batavia op 12 December 1911. Batavia: G. Kolff, 1912.

------. De Indische Partij: Haar Wezen en haar Doel. Bandung: Fortuna, 1913. 
Djamal, Murni. "The Origin of the Islamic Reform Movement in Minangkabau: Life and Thought of Abdul Karim Amrullah." Studia Islamika 5, 3 (1998).

Effendy, Bahtiar. Islam and the State in Indonesia. Singapore: ISEAS, 2003.

Eliraz, Giora. "The Islamic Reformist Movement in the MalayIndonesian World in the First Four Decades of the 20th Century: Insights Gained from a Comparative Look at Egypt." Studia Islamika 9, 2 (2002).

Henley, David E.F. Nationalism and Regionalism in a Colonial Context: Minahasa in the Dutch East Indies. Leiden: KITLV Press, 1996.

Het Licht, 1, 2 (March 1926): 102.

Hurgronje, C. Snouck. "Over Panislamisme” [1912], in A.J. Wensinck (ed.). Verspreide Geschriften van C. Snouck Hurgronje, vol. 1. Bonn: Kurt Schoeder, 1923.

------. Nederland en de Islam. 2de vermeerde drug. Leiden: E.J. Brill, 1915.

Jainuri, A. Mubammadiyah: Gerakan Reformasi Islam di Jawa pada Awal abad Kedua Puluh. Surabaya: PT Bina Ilmu, 1981.

Jamin, Moehammad. "Bangsa dan kebangsaan" [1931], in Pitut Soeharto and A. Zainoel Ihsan (eds.). Permata Terbenam; Capita Selecta Keempat. Jakarta: Aksara Jayasakti, 1982: 259.

Kahfi, Erni Haryanti. "Haji Agus Salim: His Role in Nationalist Movements in Indonesia during the Early Twentieth Century." Unpublished MA dissertation, McGill University, 1996.

Kemadjoean Hindia, 5-11 December 1925, IPO 51/1925.

Laffan, Michael Francis. Islamic Nationhood and Colonial Indonesia: The Umma below the Winds. London: RoutledgeCurzon, 2003.

Lindenborn, M. [Director, Netherlands Missionary Association]. Zendingslicht op den Islam. Den Haag: Den Boekhandel van den Zendingstudie Raad, 1918.

Mangkoepradja, Gatot. "Kebangsaan Indonesia" [1932], in Pitut Soeharto and A. Zainoel Ihsan (eds.). Permata Terbenam; Capita Selecta Keempat. Jakarta: Aksara Jayasakti, 1982: 297. 
RE Elson

Mangoenkoesoemo, Goenawan. "Ons Standpunt Tegenover den Godsdienst," in Anon. Soembangsib: Gedenkboek Boedi-Oetomo: 1908-20 Mei-1918. Amsterdam: Tijdschrift Nederl. Indië Oud \& Nieuw, 1918: 106-111.

Mangoenkoesoemo, Tjipto. Het Communisme in Indonesië: naar Aanleiding van de Relletjes. Bandung: Algemeene Studieclub, 1927.

------- Iets Over den Javaan, Zijn Geschiedenis en Zijn Ethiek. Semarang: n.p., 1913.

------. “Dr. Kuyper te laat.” Het Tijdschrift 2 (1912): 574.

------. “Geestelijke immobiliteit geeischt.” Het Tijdschrift 1 (1912), p. 17.

McVey, Ruth T. The Rise of Indonesian Communism. Ithaca: Cornell University Press, 1965.

Melayu, Hasnul Arifin. "Islam as An Ideology: The Political Thought of Tjokroaminoto." Studia Islamika 9, 3 (2002).

Mobini-Kesheh, Natalie. The Hadrami Awakening: Community and Identity in the Netherlands East Indies, 1900-1942. Ithaca: Cornell Southeast Asia Program, 1999.

Moeis, Abdoel. "Hindia boeat anak Hindia" [1917], in Pitut Soeharto and A. Zainoel Ihsan (eds.). Permata Terbenam; Capita Selecta Keempat. Jakarta: Aksara Jayasakti, 1982.

Ningrat, Surya [Suwardi Suryaningrat]. "Het Javaansch nationalisme in de Indische beweging," in Anon. Soembangsih: Gedenkboek BoediOetomo: 1908-20 Mei-1918. Amsterdam: Tijdschrift Nederl. Indië Oud \& Nieuw, 1918: 33.

Noer, Deliar. The Modernist Muslim Movement in Indonesia 1900-1942. Kuala Lumpur: Oxford University Press, 1973.

Oetoesan Hindia 9-15 January 1923, IPO 3/1923.

Panitia Peringatan Hadji A. Salim Genap Berusia 70 Tahun [Mohamad Roem et al.]. Djedjak Langkah Hadji A. Salim: Pilihan Karangan, Utjapan dan Pendapat Beliau dari Dulu sampai Sekarang. Jakarta: Tintamas, 1954.

Poensen, C. Brieven over den Islam uit de Binnenlanden van Java. Leiden: E.J. Brill, 1886. 
Poeze, Harry A. "Early Indonesian emancipation: Abdul Rivai, Van Heutsz, and the Bintang Hindia." Bijdragen tot de Taal-, Land-en Volkenkunde 145 (1989).

------. "Inleiding," in Harry A. Poeze (ed.). Politiek-politioneele overzichten van Nederlandsche-Indië vol. 1. The Hague: Martinus Nijhoff, 1982.

Radjiman. "De Maatschappelijke Loop van de Javaansche (Indonesische) Bevolking." Indisch Genootschap: vergadering van 27 February 1920: 64 and 66.

------. "Het Psychisch Leven van Het Javaansch Volk." Indisch Genootschap: Algemeene Vergadering van 14 February 1911: 154.

Ricklefs, M.C. A History of Modern Indonesia since c. 1200. 3rd ed. Basingstoke: Palgrave, 2001.

------. Mystic Synthesis in Java: A History of Islamization from the Fourteenth to the Early Nineteenth Centuries. Norwalk CT: EastBridge, 2006.

------. Polarising Javanese Society: Islamic and Other Visions (c. 1830-1930). Singapore: NUS Press, 2007.

Ronkel, Ph.S. van. Rapport Betreffende de Godsdienstige Verschijnselen ter Sumatra's Westkust. Batavia: Landsdrukkerij, 1916.

Saleh, Fauzan. Modern Trends in Islamic Theological Discourse in 20th Century Indonesia: A Critical Study. Leiden: Brill, 2001.

Shiraishi, Takashi. An Age in Motion: Popular Radicalism in Java, 19121926. Ithaca: Cornell University Press, 1990.

Soeriokoesoemo, R.M.S. "Javaansch Nationalisme," in R.M.S. Soeriokoesoemo, A Muhlenfeld, Tjipto Mangoenkoesoemo, and J.B. Wens. Javaansche of Indisch Nationalisme? Pro en Contra. Semarang: Semarang Drukkerij en Boekhandel H.A. Benjamins, 1918: 3-4.

Soeroto, Noto. "De Eendracht van Indië en Nederland." Indische Vereeniging: Voordrachten en Mededeelingen 5 (1913).

Sumartana, Th. Mission at the Crossroads: Indigenous Churches, European Missionaries, Islamic Association and Socio-religious Change in Java 1812-1936. Jakarta: BPK Gunung Mulia, 1994.

Suradi. Haji Agus Salim dan Konflik Politik dalam Sarekat Islam. Jakarta: Pustaka Sinar Harapan, 1997. 
RE Elson

Tollenaere, Herman Arij Oscar de. The Politics of Divine Wisdom: Theosopby and Labour, National, and Womens' Movements in Indonesia and South Asia, 1875-1947. Nijmegen: Uitgeverij Katholieke Universiteit Nijmegen, 1996. 